\title{
Couze Venn: thinking at the limits
}

\section{Simon Dawes ${ }^{1}$}

Published online: 4 March 2020

(c) Springer Nature Limited 2020

There are lots of things to remember Couze by. The books and journal articles he wrote and the journal issues he co-edited have left the most visible trace, but there is also all the unpublished and anonymous editorial feedback he gave over the decades as a journal editor, the weighty interventions he made in editorial meetings, not to mention the guidance he gave all those PhD students. And there is much more than that, of course.

As author, editor and supervisor, he put both the critique and the distance into critical distance. His comments were always insightful and reflective, drawing upon a breadth and depth of knowledge to historicise, contextualise and constructively critique the arguments of others, 'thinking at the limits' to connect them to wider debates and always acknowledging, in his own work, that he was doing no more than taking a few steps further down along the paths that others had already cleared out (2000, pp. 1-3).

Whenever I told anyone that he was one of my supervisors, the response was usually either 'so very well read' or 'such a lovely man'; often it was both. He was a little too well read for my immediate concerns, and I was a bit taken aback when he first suggested I read a rather long list of theorists that had no discernible connection to anything I was intending to research. But his guidance towards Foucault in particular opened my eyes to a much larger world, a much more challenging and rewarding way of doing research that was historical and discursive, theoretical and critical, and of which the special issue he co-edited with Tiziana Terranova on Foucault's lectures on neoliberalism (Venn and Terranova 2009) was such an example.

Throughout his own work, he sought to reconstruct a history of the present, not just for genealogy's sake, but to reconfigure a different, postcapitalist future (2018). He engaged critically with Foucault to provide a genealogical critique of inequality (Ashurst and Venn 2014), neoliberalism (2009, 2010a, b), colonialism (2006), race (2011, 2014) and modernity (2000), to go beyond epistemology and modernity's own concepts so as to deconstruct the conceptual and historical space in which narratives of subjectivity and history are themselves constructed.

Simon Dawes

simondawes0@gmail.com

$1 \quad$ Versailles Saint-Quentin-en-Yvelines University, Versailles, France 
His first (co-written) book, Changing the Subject (1998 [1984]), was the result of collaborative research with Julian Henriques, Wendy Hollway, Cathy Urwin and Valerie Walkerdine. Written at the time of the rise of the new right, neoliberalism and the entrepreneurial self, and drawing on critical and poststructural theory, feminism and postcolonialism, they sought to challenge and change the way the subject is understood as unitary and rational in psychology, in social theory and in the social sciences more generally. The authors sought to move psychological inquiry from Freud to Ettinger, via Lacan and post-Lacanian research, to develop an account of a multiple, relational subject not bound by reason.

Always interested in problematising subjectivity and identity (1997), and in enabling both individual and collective emancipation and liberation (2014), in subsequent writings he focused increasingly on the concept of affect (Blackman and Venn 2010) and with the work of Gilbert Simondon on relationality and individuation, and Bernard Stiegler on technics, in particular with their ideas of being as technical being, developing their work on psycho-social and symbolic associated milieu to develop his own account of psychosomatic and affective associated milieu $(2010 \mathrm{a}, \mathrm{b})$ to describe the constitution of political subjectivities. Applying these theoretical insights to contemporary problems, such as climate change and the post-financial crisis, and taking his inspiration from (as always, a critical engagement with) the efforts of Adorno and Horkheimer to understand the conditions that are conducive to fascism, fundamentalism and racism, he was turning his attention at the end to those conditions that have made possible the recent rise of neofascism (2019). Demonstrating its connections to neoliberalism and to longer counterhistories of colonialism and modernity, he was bringing all the threads of his lifework together to confront these new threats and to forge effective alternatives.

The last time we spoke (by email) was what turned out to be a month before he died. In and out of the hospice, stuck in his specialist bed, he was still working, co-editing a special issue on the commons (for Theory, Culture \& Society) and writing a journal article (for Subjectivity) on neofascism and neoliberalism. I got the impression that he was at peace with the possibility he wouldn't see either of them through to print, though I'm pleased for him (and for us) that he both finished writing and got to see in print his last book, After Capital (2018). With his usual custom of moving effortlessly from academic discussions to ruminations on life and personal banter, he spoke of the difference between the permanence of the love and support of our closest, and the temporary satisfaction of a good publication. In this balance between family and work, between permanence and temporary satisfaction, he considered giving what he could to postgrads part of the former. It's no wonder many of them still counted him as a friend, and I'm proud to have been one of them. The birds and flowers, great views and happy holidays were the things he remembered most fondly. And for us, we have so much more than his books and articles to remember him by. Not just a guide for doing scholarly research and critique, but a model for being a good scholar. 


\section{References}

Ashurst, Francesca, and Couze Venn. 2014. Inequality, Poverty, Education: A Political Economy of School Exclusion. London: Palgrave Macmillan.

Blackman, Lisa, and Couze Venn. 2010. Affect. Body \& Society 16 (1): 7-28.

Henriques, Julian, Wendy Hollway, Cathy Urwin and Valerie Walkerdine. (1998 [1984]). Changingthe Subject. London: Routledge.

Venn, Couze. 1997. Beyond enlightenment? After the subject of foucault, who comes? Theory, Culture \& Society 14 (3): 1-28.

Venn, Couze. 2000. Occidentalism, Modernity and Subjectivity. London: SAGE.

Venn, Couze. 2006. The Postcolonial Challenge. Towards Alternative Worlds. London: SAGE.

Venn, Couze. 2009. Neoliberal Political Economy, Biopolitics and Colonialism: A Transcolonial Genealogy of Inequality. Theory, Culture \& Society 26 (6): 206-233.

Venn, C. 2010a. Foucault's Analysis of Neo-Liberalism: Implications for the present. Theory, Culture \& Society. https://www.SAGEpub.net/tcs/?page=couzeneolib.

Venn, Couze. 2010b. Individuation, Relationality, Affect: Rethinking the Human in Relation to the Living. Body \& Society 16 (1): 129-161.

Venn, Couze. 2011. Introduction: Reflections on Amin's "Remainders of Race": Culture, Nature or the Political Economy of Race? Theory, Culture \& Society 28 (1): 103-111.

Venn, Couze. 2014. 'Race' and the Disorders of Identity: Rethinking Difference, the Relation to the Other and a Politics of the Commons. Subjectivity 7 (1): 37-55.

Venn, Couze. 2018. After Capital. London: SAGE.

Venn, Couze. 2019. How neoliberalism is normalising hostility. OpenDemocracy: https://www.opend emocracy.net/en/opendemocracyuk/how-neoliberalism-is-normalising-hostility/.

Venn, Couze, and Tiziana Terranova. 2009. Introduction: Thinking After Michel Foucault. Theory, Culture \& Society $26(6): 1-11$.

Publisher's Note Springer Nature remains neutral with regard to jurisdictional claims in published maps and institutional affiliations. 